\title{
Current State and Trends on International Standardization of Solid Biofuel
}

\author{
澤井＼cjkstart徹*・井田民男** \\ Toru SAWAI and Tamio IDA
}

Key Words: Solid Biofuel, International Standardization, Pellets, Briquettes, Biocoke

\section{1. 緒言}

バイオマス資源はその大部分が森林バイオマスに代表さ れる固体資源であり、バイオ固体燃料としての利活用が注 目されている。Lamers ら ${ }^{1)}$ によれ゙、バイオ固体燃料の世 界貿易量は 2000 年から 2010 年の間に、56 PJ から 300 PJ へと増大し、とりわけペレット燃料が貿易量の拡大をけん 引している。最新の報告（バイオマス白書 2014）点では、 ペレットの国際貿易量は 2011 年で 150 PJ（820 万トン）に 到達していることが示されており、これは木質ペレットの 世界生産量 2200 万トンの $37 \%$ を占めている。バイオ固体 燃料が世界的に広く利用されると同時に、世界市場で流通 するようになるにつれて、バイオ固体燃料の国際標準化が 求められるようになってきた。この要望を受けて、2014 年 に、ISO 17225 Solid biofuels - Fuel specifications and classes (バイオ固体燃料 燃料の仕様と等級 $)^{3)}$ が発行されたところ である。

本解説ではバイオ固体燃料の国際標準化の現状、産業分 野・電力分野において二酸化炭素排出削減策として導入が 期待されている石炭代替バイオ固体燃料の動向について概 観する。

\section{2. 国際標準化の現状}

2.1 ISO 17225 シリーズ概要

2014 年に発行された ISO 17225 シリーズは現段階では以 下に示す 7 つ partで構成されている。 part 1 の一般的要 件以降、part 2 と part 6 でペレットが、part 3 と part 7 でブ リケットが、part 4 で木質チップが、part 5 で薪が取り扱わ れている。今後の貿易量が大きくなると予測される熱処理 圧密燃料は part 8 に組み込まれており、2016 年 2 月時点で は草案策定中の状況である。

- Part 1: General requirements（一般的要件）
- Part 2: Graded wood pellets（等級別木質ペレット）

- Part 3: Graded wood briquettes（等級別木質ブリケット）

- Part 4: Graded wood chips（等級別木質チップ）

- Part 5: Graded firewood（等級別薪）

- Part 6: Graded non-woody pellets（等級別非木質ペレット）

- Part 7: Graded non-woody briquettes(等級別非木質ブリケッ

卜)

- Part 8: Graded thermally and densified biomass fuels（等級別 熱処理・圧密化バイオマス燃料)

part 1 の一般的要件では、バイオ固体燃料の仕様として、a) 原資源、b) 主要な貿易形態と燃料特性を示すことが規定さ れている。

主要なバイオ固体燃料の原資源を Table 1 に示す。原資 源としては、木質、草本、フルーツ、水生バイオマスの 4

Table 1 Classification of origin and sources of solid biofuels.

\begin{tabular}{|c|c|}
\hline $\begin{array}{l}\text { 木質 } \\
\text { バイオマス }\end{array}$ & 高木 (tree)、低木 (bush、shrub) 由来のバイオマス \\
\hline $\begin{array}{l}\text { 草本 } \\
\text { バイオマス }\end{array}$ & $\begin{array}{l}\text { 非木質の蓕を有し、成長する季節の最後に枯れる } \\
\text { 植物由来のバイオマス。穀物および穀物の副産物 } \\
\text { である穀草を含む }\end{array}$ \\
\hline $\begin{array}{l}\text { フルーツ } \\
\text { バイオマス }\end{array}$ & $\begin{array}{l}\text { フルーツあるいは種子を有するフルーツ植物の } \\
\text { 一部に由来するバイオマス } \\
\text { ·berries：漿果《核のない果肉の柔らかな食用小 } \\
\text { 果実》 } \\
\text { · stone/kernel fruit：核果《ウメ·モモなど堅い核 } \\
\text { のある果物》 } \\
\text { · nuts and acorns : 殼斗果《どんぐり等の殼斗の } \\
\text { ある果実》 }\end{array}$ \\
\hline $\begin{array}{l}\text { 水生 } \\
\text { バイオマス }\end{array}$ & 水生植物に由来するバイオマス \\
\hline 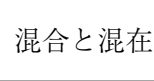 & $\begin{array}{l}\text { 混合 (blends) は意図的なバイオ燃料への混合、混 } \\
\text { 在 (mixture) は意図しない混入 }\end{array}$ \\
\hline
\end{tabular}

*近畿大学 理工学部（ $\bar{T}$ 577-8502 大阪府東大阪市小若江 3-4-1）

Faculty of Science and Engineering, Kindai University (3-4-1 Kowakae, Higashiosaka, Osaka, 577-8502 Japan)

**近畿大学バイオコークス研究所（５ 577-8502 大阪府東大阪市小若江 3-4-1）

Research Institute of Biocoke, Kindai University (3-4-1 Kowakae, Higashiosaka, Osaka, 577-8502 Japan) 
種と、これらの混合物が 5 番目に加えられている。

バイオ固体燃料の貿易形態は、21 通りに区分され、ISO 17225 中の表にまとめられている。燃料形状とサイズは、 燃料輸送時の重要な特性となると同時にその燃焼特性やハ ンドリング性能にも影響することから、貿易形態ごとにそ の主要サイズ・製造方法が示されている。また、各貿易形 態の燃料仕様は、明記すべき規範特性 (normative properties) と任意表示の参考特性 (informative properties) に分けて、個 別に表の形式で項目が規定されている。

なお、part 1 の序文において、バイオマスはエネルギー 資源であると同時に、建材、家具、紙製品のためのマテリ アル資源でもあり、カスケード的利用が大前提である旨を 示していることは重要といえる。

2.2 ペレットとブリケット

成形されたバイオ固体燃料は、そのエネルギー密度が高 く、輸送および使用時のハンドリング性の向上が期待でき ることから、世界貿易量が今後も拡大していくと見达まれ る。貿易形態における成形バイオ固体然料としては、現段 階でペレットとブリケットがある。両者の形状における仕 様の違いとして、ペレットは直径が $25 \mathrm{~mm}$ 以下、ブリケッ トは $25 \mathrm{~mm}$ より大であると規定している。本節では、ペレッ トとブリケットの仕様について概観する。

1) 木質ペレット (ISO 17225-2)

part 2 では、木質バイオマスを原資源とするペレットの 等級化とその仕様が規定されている。木質ペレットは、民 生用（住宅用・業務用）に加えて産業用のエネルギー発生 装置で使用されることを想定して、等級化がなされている。 使用対象となる燃焼機器としては、ペレットストーブ、ペ レットバーナー、ペレットボイラーが示されている。

民生用（住宅用・業務用）の等級別木質ペレットは、 A1、A2、B 級ペレットの 3 通りに区分されている。いずれ の等級も、形状の仕様は共通で、直径 D が 6 または $8 \mathrm{~mm}$ 、 長さ $\mathrm{L}$ が $3.15 \sim 40 \mathrm{~mm}$ の円柱形と規定されている。 L/D の上限が 6 程度に抑えられているのは、ペレット供給装置 での閉塞回避のためである。これら 3 つの等級における主 要な差異は、原資源とこれに伴う灰分率であり、A1、A2、 B 級に対する灰分率の上限值は $0.7 \% 、 1.2 \% 、 2.0 \%$ と規定 されている。

産業用の等級別木質ペレットは、I1、I2、I3 級ペレット の3 通りに区分されている。民生用との違いは、形状、灰 分率、機械的耐久性、粉化度、 $\mathrm{N}$ 分、 $\mathrm{S}$ 分、 $\mathrm{Cl}$ 分、微量重 金属含有量である。一般的に、産業用ペレットの燃焼機器 は、制御システムや排ガス浄化システムを有している。こ のため、民生用途の木質ペレットの仕様に比べて産業用途 では幾分緩い基準となっている。さらに、産業用では微粉 にして使用することがあるため、粒子径分布が仕様に加え られている。一例として、I1 級では、1.0 $\mathrm{mm}$ 未満が全体の
$60 \% 、 2.0 \mathrm{~mm}$ 未満が全体の $95 \% 、 3.15 \mathrm{~mm}$ 未満が全体の $99 \%$ 以下であることが仕様に与えられている。

なお、いずれの等級においても、灰融解温度が参考特性 (informative properties) に挙げられ、その值を記述すべきで あると明記されている。

2) 非木質ペレット（ISO 17225-6）

part 6 では、非木質バイオマス（草本、フルーツ、水生） を原資源とするペレットの等級化とその仕様が規定されて いる。木質ペレットと同様に、民生用（住宅用・業務用） に加えて産業用のエネルギー発生装置で使用されることを 想定して、等級化されている。使用対象となる燃燒機器と しては、ペレットバーナー、ペレットボイラー、ペレット バーナーを組み込んだ然焼システムが示されている。非木 質ペレットでは、以下に示す高灰分率の理由により、ペレッ トストーブでの使用を想定していない。

非木質ペレットの場合、その取り扱い時における注意点 が序文に述べられており、これが木質ペレットとは大きく 異なる点である。以下に主な注意事項を示す。

・非木質ペレットは、灰分、塩素、窒素、硫黄、主要な 重金属元素の含有率が高いため、非木質ペレットの ために設計あるいは調整された機器での使用を推奨す る。

・一般的に非木質バイオマスは高灰分で木質系バイオマ スと比べて低融点の灰を形成し、ボイラー内でのス

ラッギングや腐食を誘発する。

等級は非木質系バイオマスの原資源に対して A、B 級の 2 通りに区分されている。これに加えて、特定の原資源に 対する等級として、イネ葈、ミスカンサス（ススキ)、リー ドカナリーグラスで製造されるペレットの仕様が個別に規 定されている。木質ペレットの仕様と比べると、灰分率は かなり高く $\mathrm{A}$ 級、B 級でその上限值が $6 \% 、 10 \%$ となって いる。また、燃料は円柱形ではあるがそのサイズは任意で あり、直径 $\mathrm{D}$ は 6 ～ $25 \mathrm{~mm}$ 、長さ $\mathrm{L}$ は $3.15 \sim 40 \mathrm{~mm} （ \mathrm{D}=$ $6 \mathrm{~mm} \sim 10 \mathrm{~mm}$ の場合 $) 、 3.15 \sim 50 \mathrm{~mm}(\mathrm{D}=12 \mathrm{~mm} \sim 25$ $\mathrm{mm}$ の場合）と規定されている。

3) 木質ブリケット (ISO 17225-3)

part 3 では、木質バイオマスを原資源とするブリケット の等級化とその仕様が規定されている。木質ブリケットは、 基本的に民生用（住宅用・業務用）での使用を想定して等 級化がなされており、産業用のバイオ固体然料として位置 づけはない。使用対象となる燃焼機器としては、ストーブ、 暖炉、調理機器、ルームヒーター、サウナストーブ、ボイラー システムが示されている。

等級別木質ブリケットは、A1、A2、B 級の 3 通りに区 分されている。民生用（住宅用・業務用）の等級別木質ぺ レットと比較すると、ブリケットでは死分率が若干高く、 これに伴い発熱量も $10 \%$ 程度低くなっているが、化学組 成および重金属含有量の仕様はほぼ同じである。大きく異 
なるのは、形状と成形性評価に関する仕様である。ブリケッ トは、その形状が軸対称な円柱形とは限らず、直方体も含 めて種々の形状が示されている。成形性評価の仕様は、見 かけ密度 (particle density)のみであり、木質ペレットの仕 様に組み込まれている嵩密度 (bulk density)、機械的耐久性 (Mechanical durability)、粉化度 (Fines) は含まれていない。 ブリケットでは、その形状と見かけ密度が多様であり、こ れらが然焼特性に大きく影響すると考えられる。ISOの注 意事項においても、ブリケットの燃焼挙動を特徵付ける燃 焼時間が形状や見かけ密度によって変化することが指摘さ れている。燃焼挙動に関しては、ブリケットの比表面積も 大きく関与すると考えられ、各等級の仕様に比表面積が参 考特性 (informative properties) として挙げられている。明記 すべきとの記述はあるものの、明確な基準值は示されてい ない。今後はブリケットの用途に対応した比表面積の仕様 策定を検討することが必要になると考えられる。

4) 非木質ブリケット (ISO 17225-7)

part 7 では、非木質バイオマスを原資源とするブリケッ トの等級化とその仕様が規定されている。非木質ブリケッ トの用途は木質ブリケットと同様に、基本的には民生用（住 宅用・業務用）を対象としている。

非木質ペレットと同様、非木質ブリケットにおいても、 灰分、塩素、窒素、硫黄、主要な重金属元素の含有率が高 いことによる取り扱い時の注意点が序文に述べられてい る。

等級別非木質ブリケットは、A、B 級の 2 通りに区分さ れている。その仕様は、形状や成形性評価項目を除いて非 木質ペレットと同じ仕様となっている。ただし、ここでも、 比表面積が参考特性 (informative properties) として挙げられ ている。

\section{3 熱処理圧密バイオ固体燃料}

熱処理バイオ固体燃料の一つにトレファクションペレッ トがある。トレファクションは、半炭化とも呼ばれ、バ イオマス改質方法の一つとして、本庄、佐野ら ${ }^{4), 5)}$ によ り 1998 年に提唱されたたものである。200-300 ${ }^{\circ} \mathrm{C}$ の中程 度の温度域での熱分解である半炭化は、 $500{ }^{\circ} \mathrm{C}$ 以上の炭 化温度に比べて熱分解温度が低いため、これまでは“semicarbonization”あるいは “mild pyrolysis”とも呼ばれていた が、現在では “torrefaction”が主流となっている。半炭化 の主な特長を以下に示す。なお、詳細な半炭化の原理につ

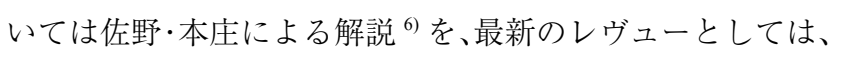

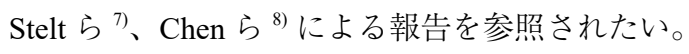

木質バイオマスは熱分解温度上昇に伴い、その色が、薄 茶色、茶色、こげ茶色、黒色へと変化する。黒色化は熱分 解によって C-C 結合が 1 重結合から 2 重結合に変化するこ とによるものである。1958 年発刊の木材工業ハンドブック によれば9)、熱分解温度に対して炭化物の名称が個別に与

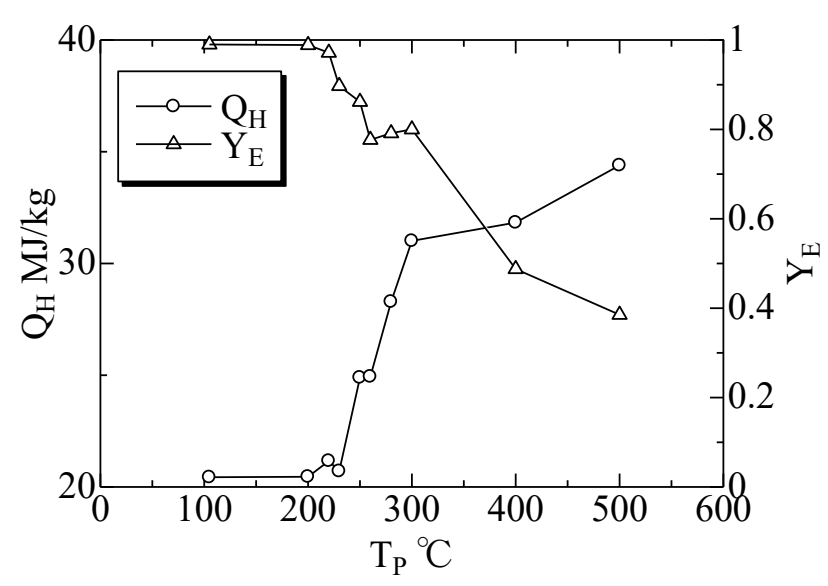

Fig.1 HHV and energy yield of torrefied biomass. [文献 10)より転載]

えられており、280 ${ }^{\circ} \mathrm{C}$ : 赤色炭、 $320{ }^{\circ} \mathrm{C}$ : 褐色炭、 $340{ }^{\circ} \mathrm{C}$ : 黒色炭、 $432{ }^{\circ} \mathrm{C}$ : 揮黒炭と呼ばれている。これより、古く から半炭化状態の炭の存在が知られていたことがわかる。

Fig.1に、スギの熱分解によって得られた残炭物の高位発 熱量 $Q_{\mathrm{H}}[\mathrm{MJ} / \mathrm{kg}]$ とエネルギー収率 $Y_{\mathrm{E}}$ を示す ${ }^{10)} 。 Y_{\mathrm{E}}$ は残炭 物の質量収率 $Y_{\mathrm{M}}$ と全乾状態の高位発熱量 $Q_{\mathrm{H} 0}$ を用いて式 (1) で与えられる。熱分解温度 $T_{\mathrm{P}}$ の増加と共に、 $Q_{\mathrm{H}}$ が増大し 改質が行われている。一方、 $Y_{\mathrm{E}}$ は徐々に減少するが、 $T_{\mathrm{P}}=$ $250-300{ }^{\circ} \mathrm{C}$ の半炭化温度域では、 $Y_{\mathrm{E}}=0.8$ 程度の高い状態 で $Q_{\mathrm{H}}=28 \mathrm{MJ} / \mathrm{kg}$ に改質されていることがわかる。すなわち、 半炭化改質は、エネルギー収率を高く保った状態での発熱 量改質である点に最大の特長を有する。

$$
Y_{E}=\frac{Y_{M} Q_{H}}{Q_{H 0}}
$$

エネルギー特性の改質に加えて、ハンドリング性の向上 に結び付く他の優れた特性も付与することができる。その 一つは、粉砕動力の低減である ${ }^{11)-13)}$ 。木質バイオマスを均 質な材料として利用するためには粉砕処理が不可欠とな る。ハンマーミルを用いた場合の粉砕所要動力を粉砕試料 の熱分解温度に対して検討した結果 ${ }^{13)}$ 、木質領域で $1-5$ $\mathrm{MJ} / \mathrm{kg}$ であった粉砕エネルギーが $T_{\mathrm{P}}=250-300{ }^{\circ} \mathrm{C}$ の半炭化 領域で約 $1 / 10$ まで減少することが明らかになった。これは 熱分解により木材の繊維構造が崩壊したためである。この ため、乾燥および半炭化処理後に粉砕工程を配置すること で、プロセス全行程のエネルギー消費を低減できる可能性 があることが示唆されている ${ }^{13)}$ 。

前述のように、熱処理バイオ固体然料についての標準化 は、part 8 で検討されているところである。仕様の詳細は未 定であるが、part 1 から part 7 に示されたバイオ固体燃料と は異なり、熱処理の進行度（熱分解の進行度）を示す仕様 として固定炭素分と揮発分が規範特性 (normative properties) 
に組み込まれることが part 1 で述べられている。

\section{3. 石炭代替バイオ固体燃料の動向}

IEA World Energy Outlook 2013 $3^{14)}$ によれば、2011 年におけ る全世界の石炭消費量は 3773 Mtoe であり、これは、世界 の 1 次エネルギー供給の $29 \%$ 、化石資源由来二酸化炭素排 出量の $45 \%$ に相当する。

温室効果ガス削減のためには、民生分野におけるバイオ 固体燃料の導入に加えて、産業分野および発電分野で使用 されている石炭あるいは石炭コークスをバイオ固体然料で 代替することがきわめて重要となる。また、「脱石炭」の動 きが世界各地で広まっている。その一例として 2015 年 11 月に OECD が加盟国の石炭火力輸出に対する融資制限を加

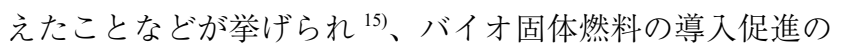
期待が高まっている。

現在の主な石炭用途とバイオ固体燃料による代替案は、 以下の通りである。

·石炭火力発電所における石炭・バイオマス混焼発電

・製鉄・鋳物・溶融炉等での石炭コークスを代替するバ イオ固体燃料の導入

なお、上記の分野では、バイオ固体燃料以外の再生可能 エネルギー（太陽、風力、バイオ気体・液体燃料）による 代替は容易ではなく、適切なバイオ固体燃料の導入と仕様 の策定が火急の課題であるといえる。

\section{1 石炭火力発電所におけるバイオマス混焼燃料}

石炭火力発電所におけるバイオマスの混焼利用では、既 に木質ペレットの利用実績があり、ISO 17225-2において 産業用ペレットの等級が定められている。さらに今後、混 焼率向上を目的にトレファクションペレット導入の可能 性が高く、これまで多くの検討 ${ }^{16)-18)}$ が行われている。ISO 17225-8の発行によりトレファクションペレットの等級と 仕様が確定すれば、混焼利用による発電分野の二酸化炭素 削減が期待できる。

\section{2 製鉄・鋳物・溶融炉等での石炭コークス代替燃料}

製鉄・鋳物・溶融炉等で使用されている石炭コークスを 代替するバイオ固体燃料 (以下、バイオコークス) としては、 これまで2つのタイプが検討されてきている。1つは炭化 熱処理を施した揮発分の少ないバイオ固体燃料であり ${ }^{19)-22) 、}$ バイオチャー、バイオコークス、バイオマスコークスと呼 ばれている。他の一つは近畿大学の井田の考案によるバイ オコークス (以下、BIC) ${ }^{23)}$ であり、非熱処理バイオマスあ るいは半炭化熱処理バイオマスを使用した成形燃料となっ ている。BICは、炭化熱処理然料に比べて、質量収率が高 いことに加え、二酸化炭素削減効果も高くなる可能性があ ることが示されている ${ }^{24)}$

バイオコークスの仕様策定に対しては、少なくとも以下 の点を満足することが要求される。
・燃焼熱による高温雲囲気形成が可能であること

・還元材として利用できること

・通気性・通液性の確保が可能であること

・製品に及ぼす影響が少ないこと

上記要求事項を満足しない場合にはキュポラ、高炉、溶 融炉が操業停止になる可能性もあり、バイオコークスの 品質評価が求められる。すなわち、バイオコークスを製造 するメーカー、バイオコークスの販売者および使用者、加 えてバイオコークスで生産された鋳物や鋼材等を使用する ユーザー等に対しても品質保証ができなければならない。 このため、バイオコークスは、単なる熱源としての燃料で はなく、バイオコークスで生産された製品（鋳物や鋼材等） に対する品質保証も求められる性格の燃料といえる。

しかしながら、バイオコークスの仕様に関する検討はこ れまで行われてきていないのが現状である。熱処理バイオ コークスは、現在検討されている ISO 17225-8 の範疇に組 み込まれると思われるが、先ほど示した製品（鋳物や鋼材 等）に対する品質保証までを具体的な仕様で規定できてい るかについては、ISO 17225-8 の発行を待って、今後検討し ていく必要がある。また、非熱処理バイオコークス (BIC) については、形状特性（直径 $25 \mathrm{~mm}$ 以上）からブリケット 燃料の一種として取り扱うことができる。しかし、現在の ISO 17225-3 または ISO 17225-7 で規定されているブリケッ トの仕様は民生用途を対象としており、バイオコークスに 求められている要件をすべて満足するとは言い難い点があ る。具体的には、2.2 節でも述べたように、ブリケットの成 形性評価が見かけ密度のみで行われている点である。高温 雲囲気での圧縮強度や燃焼特性といった特殊環境下に置か れた成形燃料の特性は、見かけ密度のみで評価することは 容易ではないと推測される、

これらの点を踏まえて、バイオコークスの仕様を策定し、 石炭コークスを代替する燃料を開発・普及させていくこと が、今後の取り組むべき課題であると考えている。

\section{4. まとめ}

本解説では、バイオ固体燃料の国際標準化の現状、産業 分野、電力分野での二酸化炭素排出削減策として期待され ている石炭・石炭コークスを代替するバイオ固体燃料の動 向について概観した。

世界における「脱石炭」の動きに加えて、2015 年パリで 開催された COP 21 の二酸化炭素削減目標を達成するため にも、石炭・石炭コークス代替のバイオ固体燃料の導入が 求められている。木質ペレットおよび次世代のトレファク ションペレットは国際標準化の流れに乗り、今後の展開が 予測されている。一方、バイオコークスは開発途上の然料 であり、その仕様について検討を進めていく必要がある。 バイオコークスの導入促進、標準化の策定が、バイオ固体 燃料分野における今後の取り組むべき重要な課題の一つに 
なっていると言える。

\section{謝 辞}

本研究の一部は、平成 27 年度近畿大学 21 世紀研究開発 奨励金の支援により行われた。ここに付記して謝意を表す る。

\section{参 考文献}

1) Lamers $P$, Junginger $M$, Hamelinck $C$ and Faaij: A Developments in international solid biofuel trade-An analysis of volumes, policies, and market factors. Renewable and Sustainable Energy Reviews, 16-5 (2012) 176-3199.

2) NPO 法人バイオマス産業社会ネットワーク、バイオマス白書 2014 (2014)、http://www.npobin.net/hakusho/2014/.

3) ISO 17225 (2014) Solid biofuels -Fuel specifications and classes.

4) 本庄孝子：未利用バイオマスの資源化：BCDFへの道、燃料 および燃焼、65 (1998) 490-497.

5) 本庄孝子、佐野寛：新燃料・BCDF バイオマス資源化、第 31 回化学工学会大会講演論文集 (1998) T301.

6) 佐野寛、本庄孝子：バイオマスの半炭化の原理と効用、高温 学会誌、37-2 (2011) 43-49.

7) M.J.C van der Stelt et al., Biomass upgrading by tor-refaction for the production of biofuels: A review, Biomass and Bioenergy, 35 (2011) 3748-3762.

8) W-H. Chen, J.Peng and X. T. Bi: A state-of-the-art review of biomass torrefaction, densification and applications, Renewable and Sustainable Energy Reviews, 44 (2015) 847-866.

9）農林省林業試験場、木材工業ハンドブック、丸善 (1958).

10）澤井徹、梶本武志、赤阪素史、加治増夫、井田民男、㴊端学、 本庄孝子、佐野寬: 杉小径木の圧縮半炭化燃料の圧縮強度 . 発熱量特性、高温学会誌、33-1 (2007) 31-37.

11) A. Morita, T. Ida, T. Sawai, K. Namba and M. Fuchihata: Comminution and combustion properties of mixture of semicarbonized woody biomass and coal, J. JSEM, 9 (2009) 36-41.

12) V. Repellin, A. Govin, M. Rolland and R. Guyonnet: Energy requirement for fine grinding of torrefied wood, Biomass and
Bioenergy, 34 (2010) 923-930.

13）西健治、澤井徹、他 4 名: 木質系粉砕物燃料の前処理工程（粉 砕、乾燥、半炭化改質）および輸送におけるエネルギー消費 量の低減、高温学会誌、37-2 (2011) 63-70.

14) IEA (2013) IEA World Energy Outlook 2013.

15) 日経産業新聞 2015 年 12 月 1 日

16) N. Ooiwa: Evaluation of a new biomassfuel aimed at the improvement in mixed combustion rate, Chubu electric power news on development of technology, 148 (2013) 11-12.

17) L. J. R. Nunes, J. C. O.Matias and J. P. S. Catalão: A review on torrefied biomass pellets as a sustainable alternative to coal in power generation, Renewable and Sustainable Energy Reviews, 40 (2014) 153-160.

18) D. Agar, J. Gil, D. Sanchez, I. Echeverria and M. Wihersaari: Torrefied versus conventional pellet production - A comparative study on energy and emission balance based on pilot-plant data and EU sustainability criteria, Applied Energy, 138 (2015) 621-630.

19) T. Yoshida, S. Q. Turn, R. S. Yost, Jr M. J. Antal: Banagrass vs Eucalyptus wood as feedstocks for metallurgical biocarbon production. Ind. Eng. Chem. Res., 47 (2008) 9882-9888.

20) Jung Su-Hwa, Oh Seung-Jin, Choi Gyung-Goo and Kim Joo-Sik: Production and characterization of microporous activated carbons and metallurgical bio-coke from waste shell biomass. Journal of Analytical and Applied Pyrolysis, 109 (2014) 123-131.

21) A. Adrados, I. De Marco, A. Lopez-Urionabarrenechea, J. Solar and B. Caballero: Avoiding tar formation in biocoke production from waste biomass. Biomass and Bioenergy, 74 (2015) 172-179.

22) 柏原友、西本薰、田中宏和、梶山博久、石田吉浩、長田守弘: シャ フト炉式ガス化溶融炉におけるバイオマスコークスの実機適 用〜 $\mathrm{CO}_{2}$ フリー化の達成〜 新日鉄エンジニアリング技報、3 (2012) 13-18.

23) T. Ida, A. Nakanishi, Osaka TLO, Patent Number 4088933: Biocoke, "BIC" (2006),

24) T. Sawai, I. Katayama, T. Ida, and T. Kajimoto: Estimation of Energy Density and Energy Yield of Torrefied Biomass with Colorimetric Values, Proc of International Conference on Power Engineering-15 (ICOPE-15) (2015). 